\title{
Assessment of impact of climate change on rice and wheat yield in sub humid climate of Bihar
}

\author{
SUNIL KUMAR* and SUJEET KUMAR ${ }^{1}$ \\ Department of Agronomy, Bihar Agricultural University, Sabour, Bhagalpur, Bihar-813210 \\ ${ }^{1}$ Tiger Analytics, Chennai, Tamilnadu \\ *Corresponding Author E-mail: iitsunil@gmail.com
}

\begin{abstract}
ABSTARCT
The present study deals with the impact of temperature and $\mathrm{CO}_{2}$ projection obtained for different time periods 2020, 2050 and 2080 using HADCM3 factors on the productivity of rice and wheat crop at four stations viz. Pusa, Purnea, Sabour and Patna of Bihar using InfoCrop model performed. The results showed that the simulated yield of rice and wheat decreased in the range of $1.1-9.2 \%, 6.1-13.2 \%$ and $15.9-22.4 \%$ from baseline in 2020, 2050 and 2080 respectively over the stations. Decrease in simulated yield in wheat was observed in the range of $3.5-21.1 \%, 14.0-37.9 \%$ for 2050 and 2080 for all the stations.
\end{abstract}

Key words : Climate change, rice, wheat, simulation studies, $\mathrm{CO}_{2}$ conc., temperature rise

The climate sensitivity of agriculture is uncertain, as there is regional variation of extreme temperature and rainfall, the crop and cropping system, soils and management practices.Inter-Governmental Panel on Climate change (IPCC) Fifth Assessment Report concludes that increasing numbers of warm days and decreasing numbers of cold days have been observed, with the warming trend continuing into the new millennium (IPCC 2014). General Circulation Models (GCMs) and Special Report on Emission Scenarios (SRES), show that higher temperatures will lead to lower rice yields as a result of shorter growing periods. However, carbon dioxide $\left(\mathrm{CO}_{2}\right)$ fertilization may at least in part offset yield losses in rice and other crops. In the Indo-Gangetic Plains of South Asia there could be a decrease of about $50 \%$ in the most favourable and high-yielding wheat area as a result of heat stress at two times $\mathrm{CO}_{2}$ (IPCC 2014). Elevated $\mathrm{CO}_{2}$ besides affecting the crop also affects the environment, which in turn may either beneficial or damaging effect on agricultural production (Rosenzweig et al., 1998). Changes in temperature play a crucial role in determining crop productivity (Fiscus et al., 1997). Decline in potential yield of wheat and rice is linked to negative trend in solar radiation and an increase in minimum temperature in the Indo-Gangetic Plains of India (Pathak et al., 2003). With subsequent rise in temperature reduced the yield of wheat and enhanced $\mathrm{CO}_{2}$ was unable to counter balance the decline in wheat yield (Abdul Haris et al., 2013). Decision support systems (DSS) or crop models provide a way, where the relative effects of these variables on crop growth and yield can be studied in particular combinations on regional basis. The present study deals with the effects of climate change on kharif and rabi season crops (Rice and wheat) for Bihar which might help to adopt suitable farming techniques to maximise agricultural production in this high potential region. It also provides insights into possible changes in the cropping pattern and adaptation options for future.

\section{MATERIALS AND METHODS}

Bihar is located in the alluvial plains of India and is situated between $24^{\circ} \mathrm{N}$ and $27^{\circ} \mathrm{N}, 83^{\circ} \mathrm{E}$ and $88^{\circ} \mathrm{E}$ with a height of $52 \mathrm{~m}$ amsl having normal rainfall of $1243.7 \mathrm{~mm}$. Four different station stations were selected representing different zones (Pusa zone I; Purnea zone II; Sabour zone III A; Patna zone III B).Daily data for air temperature and rainfall from four representative centres were collected for the period 1955-2010 for Pusa and Sabour and 1969-2010 for Patna and Purnea. Meteorological, crop and soil data used for the simulation studies were collected from India Meteorological Department, Pune; Rajendra Agricultural University, Pusa and Bihar Agricultural University, Sabour.

IPCC describes future scenarios for the period 20102039, 2040-2069 and 2070-2099 referred to as 2020 $2050_{\mathrm{s}}$ and $2080_{\mathrm{s}}$ respectively. The General Circulation Model was used in the study $\left(\mathrm{HADCM}_{3}\right)$ for the $\mathrm{A}_{2}$ scenarios (The $\mathrm{A}_{2}$ scenario describes a heterogeneous world with a focus on selfreliance and preservation of local identities. Fertility patterns across regions converge very slowly, which results in continuously increasing population). The generic crop 
Table 1: Study area representing different agro-ecological zones of Bihar

\begin{tabular}{lllll}
\hline Station & Agro- ecological zone & Latitude $\left({ }^{\circ} \mathrm{N}\right)$ & Longitude $\left({ }^{\circ} \mathrm{E}\right)$ & Elevation $(\mathrm{m})$ \\
\hline Pusa & I & 25.85 & 85.78 & 47 \\
Purnea & II & 25.98 & 87.80 & 53 \\
Sabour & III A & 26.10 & 87.70 & 37 \\
Patna & III B & 25.58 & 85.25 & 41 \\
\hline
\end{tabular}

Table 2: Validation results for rice and wheat crops

\begin{tabular}{lrrrr}
\hline Crop & Coefficient of efficiency (\%) & ${\text { RMSE }\left(\mathrm{kg} \mathrm{ha}^{-1}\right)}$ & $\mathrm{MAE}\left(\mathrm{kg} \mathrm{ha}^{-1}\right)$ & $\mathrm{R}^{2}$ \\
\hline Rice (var. Swarna) & 70 & 291.5 & 236 & 0.87 \\
Wheat (var. HD 2733) & 85 & 105.2 & 71 & 0.90 \\
Wheat (var. PBW 343) & 84 & 162.1 & 132 & 0.89 \\
\hline
\end{tabular}

RMSE $=$ Root mean square error; $\quad M A E=$ Mean absolute error.

Table 3:Percentage change in yield ofrice and wheatcrop due to climate change

\begin{tabular}{llllllll}
\hline & \multicolumn{3}{c}{ Rice } & & \multicolumn{3}{c}{ Wheat } \\
\cline { 2 - 4 } \cline { 6 - 7 } Stations & 2020 & 2050 & 2080 & & 2020 & 2050 & 2080 \\
\hline Pusa & -1.3 & -8.6 & -19.1 & & 2.6 & -3.5 & -14.0 \\
Purnea & -1.4 & -11.4 & -22.4 & & -5.0 & -13.0 & -20.0 \\
Sabour & -1.1 & -6.1 & -15.9 & & -3.7 & -18.7 & -35.4 \\
Patna & -9.2 & -13.2 & -19.9 & & -11.0 & -21.1 & -37.9 \\
\hline
\end{tabular}

model Info Crop ver. 2.1 developed at IARI, Pusa (Aggarwal, et al., 2004) was used. Info Crop is a DSS, designed to simulate the effects of weather, soil, agronomic management and major pests on crop growth and yield. The model was calibrated by comparing the simulation yield with the observed yield for three years. Calibration in the case of rice for var. Swarna and for two different varieties of wheatHD 2733 and PBW 343 for different locations, viz. Pusa, Purnea, Sabour and Patna respectively was done according to crop yield data availability. Generic coefficients were derived for rice var. Swarna and for wheat var. HD 2733 and PBW 343 growing in the major area. The results of validation are presented in Table 1. After calibration, the model was run for the baseline and scenarios based on the practices used for validation purposes. Sensitivity analysis was performed for Swarna var. of rice and HD 2733 and PBW 343 varieties of wheat crop to know the role of projected changes of temperature in various combinations. The growth and yield of rice and wheat under different changing scenarios was simulated using the model. Potential yields of rice and wheat were first simulated at current level of $\mathrm{CO}_{2}$ for the baseline period (1961-1990). Further the different scenarios were given for 2020, 2050 and 2080 respectively, as incremental variable scenarios have the capacity of capturing a wide range of possible changes in the near future.

\section{RESULTS AND DISCUSSION}

Change in yield of rice and wheat crop due to climate change

Simulated yield of rice in different scenario decreased the yield in all the periods. This decrease was in the range of $1.1-9.2 \%, 6.1-13.2 \%, 19.1-22.2 \%$ for 2020,2050 and 2080 respectively for all the stations (Table 3). Maximum decrease in yield was observed in Patna for 2020 and 2050 but in 2080, it was maximum in Purnea.These results are in line with those of other researchers. For instance, Peng et al.(2004) observed that yield of rice decreased by $10 \%$ for every $1^{0}$ $\mathrm{C}$ rise in growing season $\mathrm{T}_{\min }$.

Simulated yield of wheat decreased from the baseline in 2050 and 2080 to $3.5-14 \%, 13-20 \%, 18.7-35.4 \%$ and $21.1-$ $37.9 \%$ for Pusa, Purnea, Sabour and Patna respectively. Simulated yield was also decreased for 2020 by $5 \%, 3.7 \%$ and $11 \%$ for Purnea, Sabour and Patna respectively.A decline of 0.45 tonne $\mathrm{ha}^{-1}$ in wheat yield, with increase in temperature from $0.5^{\circ} \mathrm{C}$ to $1.5^{\circ} \mathrm{C}$ has been reported by Kalra et al.(2003). The impact of climate change was more on wheat than rice. This may be ascribed to the increased projected $\mathrm{T}_{\min }$ and $\mathrm{T}_{\max }$ and decreased rainfall in the months of Feb to March synchronizing reproductive and grain development stages of wheat. All these conditions reduce 
both duration to anthesis and to maturity, leading to poor grain fill in wheat (Arora et al. 1998). Moreover, at high temperature, energy is lost through the process of transpiration by the plant and reduced energy results in poor grain formation and yield. Such effects are less in rice because of relatively lower temperature at maturity and these may not aggravate in future as the projected temperature rise is also less. In the present study, a strong correspondence between reduction in yield and shortening of crop duration under higher temperature was observed in scenarios.

\section{CONCLUSION}

The study indicates losses in the yield of rice and wheat with subsequent rise in temperature. However, the percentage decline was more in zone II and III B in case of rice, probably due to more decline of rainfall in future. In case of wheat, decline in yield was more in zone III A and III $\mathrm{B}$, probably due to more increase of minimum temperature in these zones. Notwithstanding these uncertainties, climate change will drive reductions in crop yield. Adaptation options, such as adopting new agronomic practices and delineating favourable areas for rice and wheat production, need to be looked into for sustainability of food security in this region.

\section{ACKNOWLEDGMENTS}

The first author is thankful to Bihar Agricultural University, Sabour for providing platform for the research. We are also thankful to the India Meteorological Department, Pune for providing weather data. The authors are also thankful for the suggestions provided by the referees and editor which resulted in significant improvement. BAU COMMUNICATIONNO 143/2016

\section{REFERENCES}

Aggarwal, P. K., Kalra, N., Chander, S. and Pathak, H. (2004). Infocrop: a generic simulation model for annual crops in tropical environments. Indian Agricultural Research Institute, New Delhi.

Arora, V.K. and Gajri, P.R. (1998). Evaluation of a crop growthwater balance model for analyzing wheat responses to climate and water limited environments. Field Crops
Res. 59:213-224.

Fiscus, E. L., Reid, C. D., Miller, J. E. and Heagle, A. S. (1997). Elevated $\mathrm{CO}_{2}$ reduces $\mathrm{O}_{3}$ flux and $\mathrm{O}_{3}$ induced yield losses in soybeans: possible implications for elevated $\mathrm{CO}_{2}$ studies. J. Exp. Bot., 48: 307-313.

Hijioka, Y., Lin, E., Pereira, J. J., Corlett, R. T., Cui, X., Insarov G. E., Lasco, R. D., Lindgren, E. and Surjan, A.(2014). Asia. In: Climate Change 2014: Impacts, Adaptation, and Vulnerability. Part B: Regional Aspects. Contribution of Working Group II to the Fifth Assessment Report of the Intergovernmental Panel on Climate Change.

Jalota, S.K., Kaur, H., Ray, S. S., Tripathy, R., Vashisht, B. B. and Bal, S. K. (2013). Past and general circulation modeldriven future trends of climate change in central Indian Punjab: ensuring yield of rice-wheat cropping system. CurrentSci., 104(1): 105-109.

Jalota, S.K., Ray, S.S. and Panigrahy, S.(2009). Effects of elevated $\mathrm{CO}_{2}$ and temperature on productivity of three main cropping systems in Punjab of India-a simulation analysis. In:ISPRS Achieves XXXVIII-8/W3 Workshop Proceedings: Impact of climate Change on Agriculture. Panigrahy, S., Ray, S.S. and Parihar, J.S.(Eds.)pp. 135142.

Kalra, N. et al. (2003). Impacts of climate change on Agriculture In Climate Change and India:Vulnerability Assessment and Adoption (eds. Shukla, P.R. etal.), Orient Longman Private LTD. Hyderabad, pp. 191-226.

Pathak, H. L. et al. (2003). Climate potential and on farm yield trends of rice and wheat in the Indo-Gangetic Plains. Field Crops Res., 80: 223-234.

Peng, S. et al. (2004). Rice yield decline with higher night temperature from global warming. Proc. Natl. Acad. Sci. USA, 101:9971-9975.

Rosenzweig, C. and Hillel, D. (1998). Climate Change and Global Harvest, Oxford UniversityPress, Oxford, U.K. pp. 135-154.

Vahab, A., Haris, A., Biswas, S., Chhabra, V., Elanchezhian, R. and Bhatt, B. P. (2013). Impact of climate change on wheat and winter maize over a sub-humid climate environment, Current Sci., 104(2): 206-214. 